\title{
Table Rock Lake Water-Clarity Assessment Using Landsat Thematic Mapper Satellite Data
}

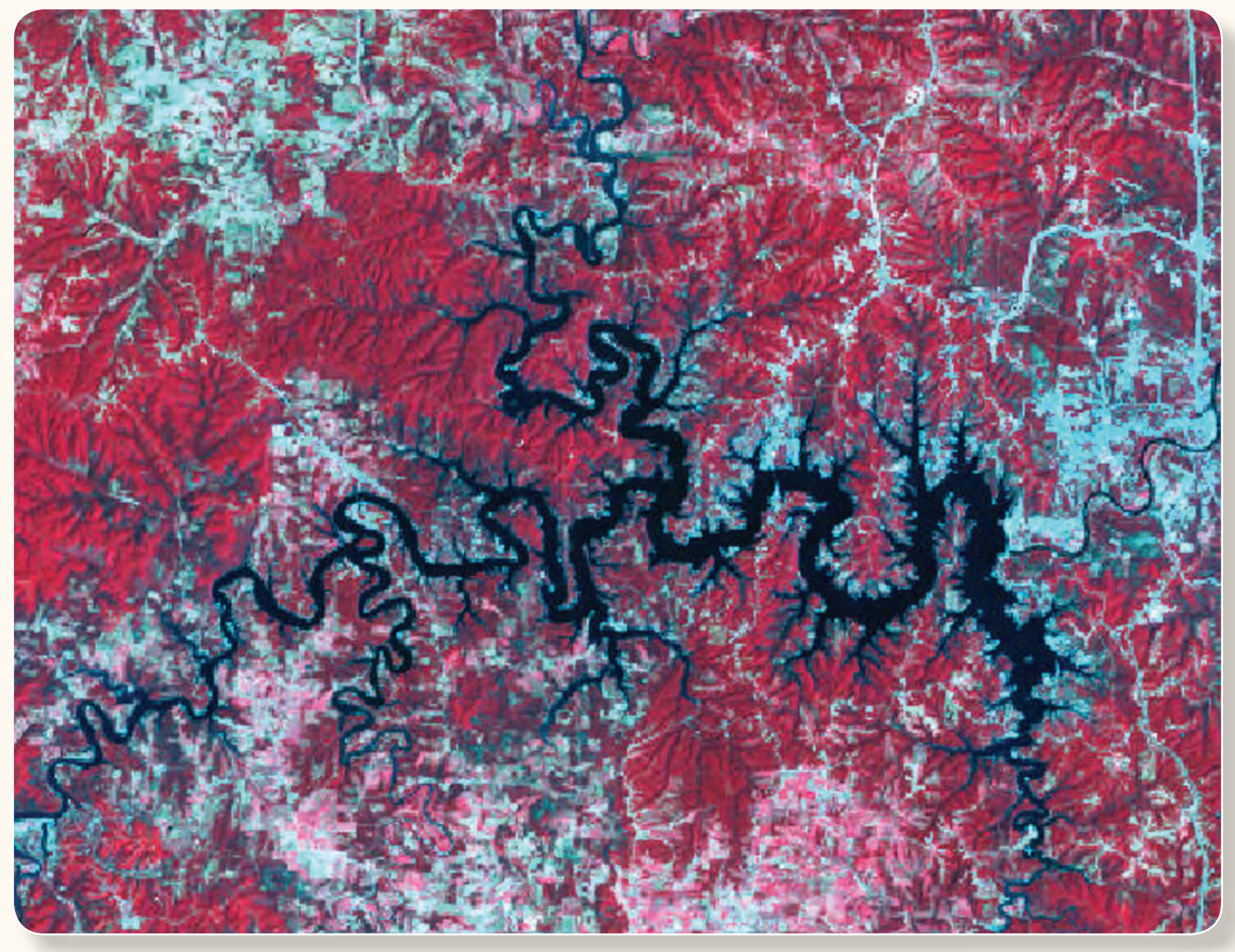

Scientific Investigations Report 2009-5162 
Cover illustration. Landsat satellite image from the Table Rock Lake area, southwestern Missouri and northwestern Arkansas. 


\section{Table Rock Lake Water-Clarity Assessment Using Landsat Thematic Mapper Satellite Data}

By Gary W. Krizanich and Michael P. Finn

Scientific Investigations Report 2009-5162 


\title{
U.S. Department of the Interior \\ KEN SALAZAR, Secretary
}

\author{
U.S. Geological Survey \\ Suzette M. Kimball, Acting Director
}

\section{U.S. Geological Survey, Reston, Virginia: 2009}

\begin{abstract}
For more information on the USGS - the Federal source for science about the Earth, its natural and living resources, natural hazards, and the environment, visit http://www.usgs.gov or call 1-888-ASK-USGS

For an overview of USGS information products, including maps, imagery, and publications, visit http://www.usgs.gov/pubprod

To order this and other USGS information products, visit http://store.usgs.gov
\end{abstract}

Any use of trade, product, or firm names is for descriptive purposes only and does not imply endorsement by the U.S. Government.

Although this report is in the public domain, permission must be secured from the individual copyright owners to reproduce any copyrighted materials contained within this report.

Suggested citation:

Krizanich, G. W., and Finn, M. P., 2009, Table Rock Lake water-clarity assessment using landsat thematic mapper satellite data: U.S. Geological Survey Scientific Investigations Report 2009-5162, 9 p. 


\section{Contents}

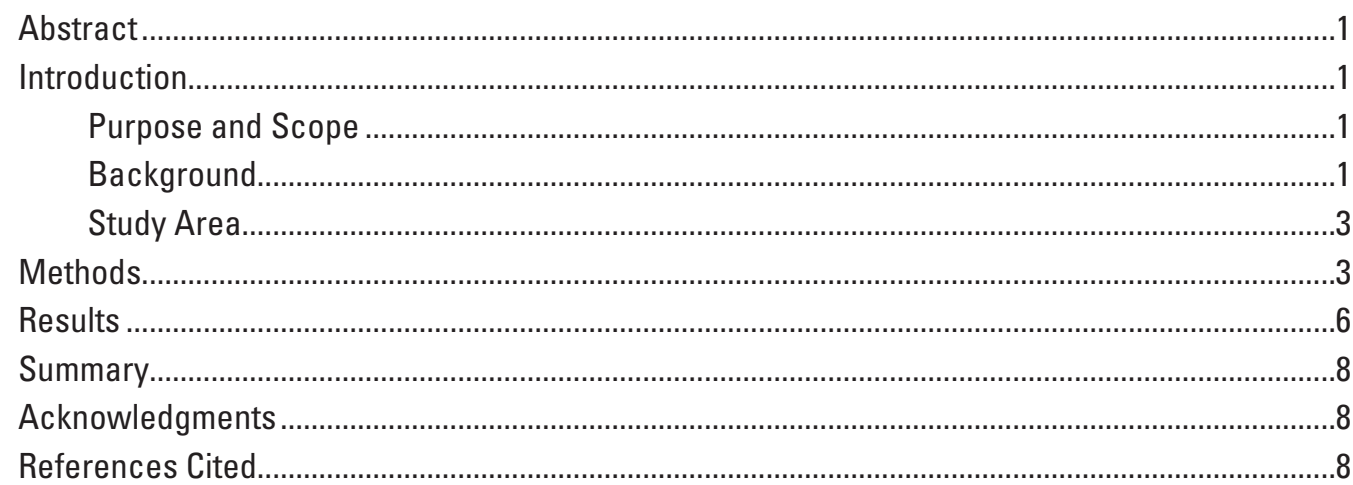

\section{Figures}

1-2. Maps showing:

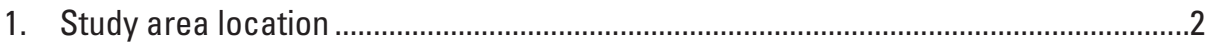

2. Table Rock Lake sample locations............................................................................

3-4. Graphs showing:

3. Relation between predicted and measured values of secchi depth in meters for Table Rock Lake.

4. Distribution of field samples with respect to number of days within satellite overpass.......

5-6. Maps showing:

5. Model predicted trophic state for Table Rock Lake - August 2003. ...........................7

6. Temporal comparison of model results for the James River arm of Table Rock Lake.....

\section{Tables}

1. Mean Landsat brightness values for Table Rock Lake sample sites 2003 and 2005 .........4 


\section{Conversion Factors, Abbreviations, and Datums}

\begin{tabular}{lcl}
\multicolumn{1}{l}{ Inch/Pound to SI } & & \\
\hline Multiply & By & \multicolumn{1}{c}{ To obtain } \\
\hline mile (mi) & Length & kilometer $(\mathrm{km})$ \\
\hline & 1.609 & \\
\hline acre & Area & square meter $\left(\mathrm{m}^{2}\right)$ \\
acre & 4,047 & hectare $($ ha) \\
acre & 0.4047 & square hectometer $\left(\mathrm{hm}^{2}\right)$ \\
acre & 0.4047 & square kilometer $\left(\mathrm{km}^{2}\right)$ \\
\hline
\end{tabular}

SI to Inch/Pound

\begin{tabular}{lll}
\hline \multicolumn{1}{c}{ Multiply } & By & To obtain \\
\hline Leter $(\mathrm{m})$ & Length & \\
\hline & 3.281 & foot $(\mathrm{ft})$ \\
\hline square meter $\left(\mathrm{m}^{2}\right)$ & 0.0002471 & acre \\
hectare (ha) & 2.471 & acre \\
square hectometer $\left(\mathrm{hm}^{2}\right)$ & 2.471 & acre \\
square kilometer $\left(\mathrm{km}^{2}\right)$ & 247.1 & acre \\
\hline
\end{tabular}

Vertical coordinate information is referenced to the North American Vertical Datum of 1988 (NAVD 88).

Horizontal coordinate information is referenced to the North American Datum of 1983 (NAD 83).

Altitude, as used in this report, refers to distance above the vertical datum. 


\title{
Table Rock Lake Water-Clarity Assessment Using Landsat Thematic Mapper Satellite Data
}

\author{
By Gary W. Krizanich and Michael P. Finn
}

\begin{abstract}
Water quality of Table Rock Lake in southwestern Missouri is assessed using Landsat Thematic Mapper satellite data. A pilot study uses multidate satellite image scenes in conjunction with physical measurements of secchi disk transparency collected by the Lakes of Missouri Volunteer Program to construct a regression model used to estimate water clarity. The natural log of secchi disk transparency is the dependent variable in the regression and the independent variables are Thematic Mapper band 1 (blue) reflectance and a ratio of the band 1 and band 3 (red) reflectance. The regression model can be used to reliably predict water clarity anywhere within the lake. A pixel-level lake map of predicted water clarity or computed trophic state can be produced from the model output. Information derived from this model can be used by waterresource managers to assess water quality and evaluate effects of changes in the watershed on water quality.
\end{abstract}

\section{Introduction}

Table Rock Lake is a primary water resource located in southwestern Missouri with tourism related activities within the watershed accounting for more than a billion dollars in revenue each year (Missouri Department of Natural Resources, 2005). Decreasing water clarity in Table Rock Lake has caused concern with water-resource managers and private watershed groups. The reservoir was listed in 2002, in accordance with section 303(d) of the Federal Clean Water Act, as having impaired water quality because of nutrient enrichment. Long-term monitoring of the reservoir by University of Missouri researchers documents an increase in nutrients and chlorophyll with a corresponding decrease in water clarity over the past 20 years (Jones and Perkins, 1999). Increases in nitrogen and phosphorus inputs to the reservoir have been attributed to point and nonpoint sources, with major contributions from wastewater treatment, urban storm water, and agricultural runoff (Missouri Department of Natural Resources, 2005). This report evaluates a remote sensing methodology for predicting water quality using satellite reflectance data and water clarity measured by secchi disk transparency.

\section{Purpose and Scope}

The purpose of this report is to describe the methods and techniques used to develop a predictive model for estimating Table Rock Lake water quality based on satellite observations combined with field-data collection. The techniques described can be used to calculate estimates of water clarity from secchi disk transparency or a lake trophic state index derived from these measurements. Model outputs can be applied to the entire water body enabling water-resource managers to identify areas of potential concern.

\section{Background}

Eutrophication is the process of organic enrichment of lake water with respect to time (Wetzel, 2001). It is a natural aging process experienced by all lakes. Nutrient supplies primarily are derived from atmospheric and terrestrial sources, the latter being more significant with runoff being the principal source of nutrients in lakes. Increased levels of nutrients result in increased biological productivity, which can have harmful effects to water supplies.

Trophic state is a measure of a lake's productivity and is commonly used to assess water quality. Eutrophy is a state of high nutrient enrichment usually associated with declining water quality. The Carlson trophic state index (1977) is a numeric index commonly used for trophic state assessment of lakes, and is based on the relation between algal biomass and secchi disk transparency depth. The index ranges from 0 to 100 with each increase of 10 units on the trophic state index equivalent to a doubling of algal biomass and can be computed from chlorophyll a concentration, total phosphorus concentration, or secchi disk transparency values.

Remote sensing methods can be effective for waterquality monitoring and water-resource assessments (Ritchie and others, 2003). Advantages include multispectral band capabilities, repetitive coverage, a historical archive dating from the early 1970s, and the ability to cover large geographic areas with a single image scene. Early studies by Boland 


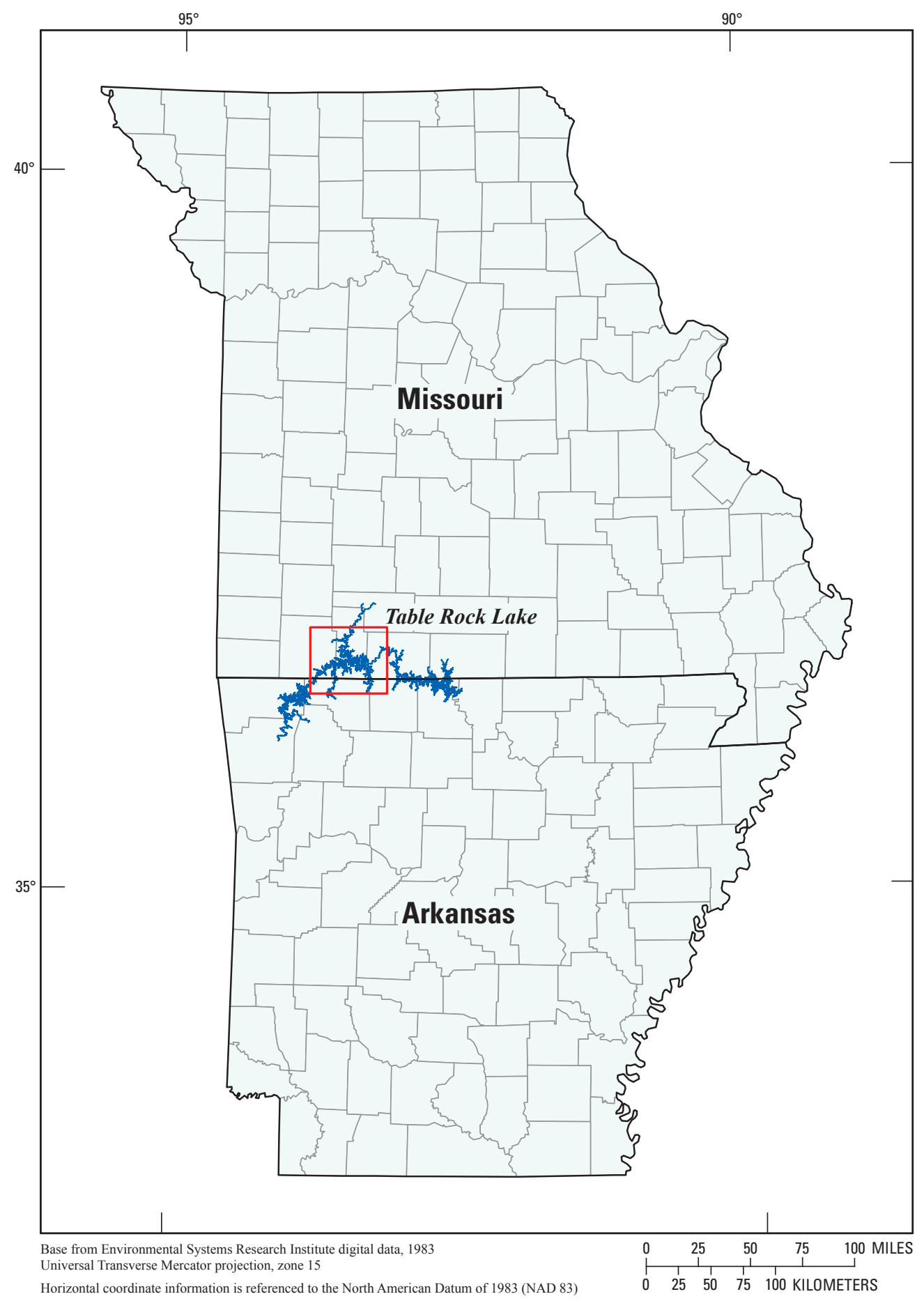

Figure 1. Study area location.

(1976) and Wezernak and others (1976) utilized complex multivariate statistical techniques for computation of a trophic state index based on reflectance data obtained from Landsat Multispectral Scanner (MSS) data. Their studies found that secchi disk transparency and chlorophyll a concentration could be used in conjunction with Landsat mean reflectance values to accurately predict lake trophic state. Increased spatial and radiometric resolution of the Thematic Mapper (TM) sensor provided improved accuracy of water-quality models derived from satellite observations (Lathrop and Lillesand, 1986). The empirical relation between secchi disk depth measurements and Landsat TM reflectance has been used to predict regionwide lake water clarity (Chipman and others, 2004; Fuller and others, 2004). Previous studies of Ozark lakes have shown that Landsat MSS and TM data can be effective in predicting water quality based on regression models developed from chlorophyll a and secchi disk depth data (Krizanich, 1986; Allee and Johnson, 1999). 


\section{Study Area}

Table Rock Lake, located in southwestern Missouri and northwestern Arkansas (fig. 1), is a U.S. Army Corps of Engineers reservoir completed in 1959 to provide flood control and power generation in the Upper White River Basin. The reservoir has a surface area of 43,100 acres with 745 miles of shoreline. It is one of four reservoirs impounding the White River with Beaver Lake immediately upstream and Lake Taneycomo and Bull Shoals Lake downstream. Table Rock Lake is located within the Springfield Plateau of the Ozark Dome, an area dominated by relatively flat-lying carbonate rocks. Land cover of the area is predominantly forest and pasture, but increasing urban development within the watershed has the potential to affect water quality (Thorpe and others, 2005).

\section{Methods}

Two Landsat 5 Thematic Mapper scenes (8/22/2003, 8/11/2005) were purchased from the Earth Resources Observation and Science (EROS) center in Sioux Falls, South Dakota. Landsat images were formatted as GeoTIFF and projected to Universal Transverse Mercator, North American Datum 1983, Zone 15. Both scenes are from Worldwide Reference System 2 path 25, row 35 and were selected based on minimal scene cloud cover and closeness of the scene date to field data collection. The scenes were processed by EROS to level 1P specifications, which include radiometric and geometric correction as well as the use of 25 ground-control points to improve geometric accuracy.

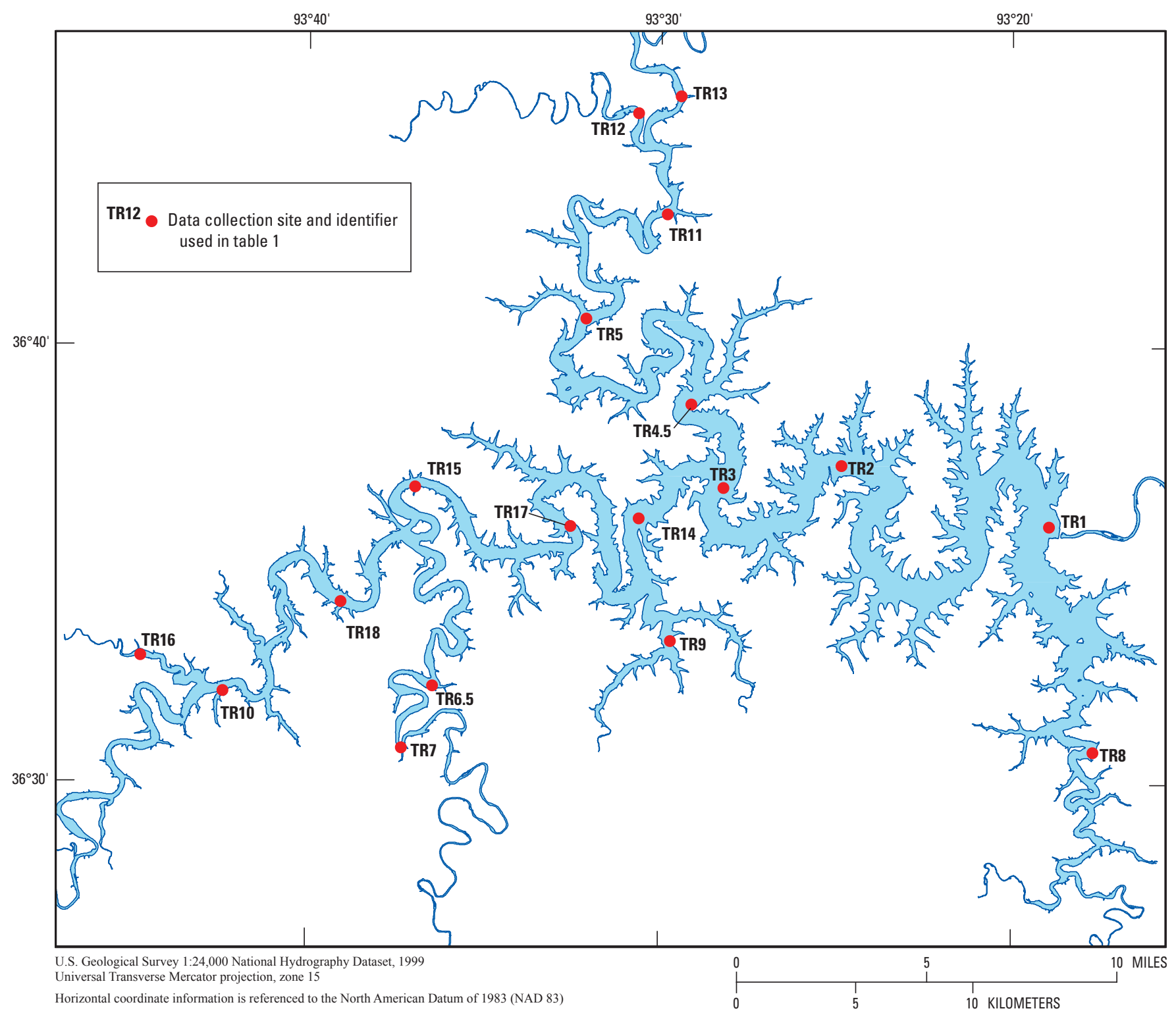

Figure 2. Table Rock Lake sample locations. Red dots indicate Lakes of Missouri Volunteer Program data collection sites. 
Table 1. Mean Landsat brightness values for Table Rock Lake sample sites 2003 and 2005.

[TM1 and TM3, Thematic Mapper bands]

\begin{tabular}{|c|c|c|c|c|c|c|c|}
\hline $\begin{array}{l}\text { Data collection } \\
\text { site (fig. 2) }\end{array}$ & Year & $\begin{array}{l}\text { Pixel } \\
\text { count }\end{array}$ & TM1 & TM3 & TM1/TM3 & $\begin{array}{l}\text { Secchi } \\
\text { (meters) }\end{array}$ & $\begin{array}{c}\text { In Secchi } \\
\text { (meters) }\end{array}$ \\
\hline TR1 & 2003 & 9 & 80 & 24 & 3.3 & 4.9 & 1.6 \\
\hline TR2 & 2003 & 9 & 80 & 23 & 3.4 & 4.0 & 1.4 \\
\hline TR3 & 2003 & 9 & 78 & 22 & 3.5 & 3.9 & 1.4 \\
\hline TR4.5 & 2003 & 9 & 78 & 23 & 3.4 & 2.7 & 1.0 \\
\hline TR5 & 2003 & 9 & 79 & 24 & 3.3 & 1.9 & 0.6 \\
\hline TR6.5 & 2003 & 9 & 82 & 27 & 3.1 & 1.5 & 0.4 \\
\hline TR8 & 2003 & 9 & 75 & 21 & 3.6 & 3.5 & 1.3 \\
\hline TR9 & 2003 & 9 & 82 & 27 & 3.1 & 2.4 & 0.9 \\
\hline TR10 & 2003 & 9 & 83 & 26 & 3.2 & 2.4 & 0.9 \\
\hline TR11 & 2003 & 9 & 79 & 26 & 3.1 & 1.1 & 0.1 \\
\hline TR12 & 2003 & 9 & 80 & 28 & 2.9 & 0.8 & -0.3 \\
\hline TR13 & 2003 & 9 & 80 & 27 & 3.0 & 0.9 & -0.1 \\
\hline TR14 & 2003 & 9 & 77 & 22 & 3.5 & 3.8 & 1.3 \\
\hline TR15 & 2003 & 9 & 78 & 24 & 3.3 & 3.2 & 1.2 \\
\hline TR16 & 2003 & 9 & 80 & 28 & 2.9 & 1.4 & 0.3 \\
\hline TR17 & 2003 & 9 & 79 & 23 & 3.4 & 3.0 & 1.1 \\
\hline TR18 & 2003 & 9 & 86 & 28 & 3.1 & 3.0 & 1.1 \\
\hline TR1 & 2005 & 9 & 66 & 17 & 3.8 & 4.1 & 1.4 \\
\hline TR2 & 2005 & 9 & 67 & 17 & 3.8 & 2.0 & 0.7 \\
\hline TR3 & 2005 & 9 & 65 & 16 & 4.0 & 3.6 & 1.3 \\
\hline TR4.5 & 2005 & 9 & 65 & 16 & 4.0 & 2.6 & 1.0 \\
\hline TR5 & 2005 & 9 & 64 & 18 & 3.6 & 1.3 & 0.3 \\
\hline TR6.5 & 2005 & 9 & 64 & 19 & 3.4 & 1.6 & 0.5 \\
\hline TR7 & 2005 & 9 & 62 & 19 & 3.3 & 0.7 & -0.3 \\
\hline TR8 & 2005 & 9 & 65 & 18 & 3.6 & 1.0 & 0 \\
\hline TR9 & 2005 & 9 & 65 & 18 & 3.6 & 3.0 & 1.1 \\
\hline TR10 & 2005 & 9 & 67 & 18 & 3.8 & 3.6 & 1.3 \\
\hline TR11 & 2005 & 9 & 65 & 19 & 3.4 & 1.1 & 0.1 \\
\hline TR12 & 2005 & 9 & 67 & 23 & 3.0 & 0.8 & -0.2 \\
\hline TR13 & 2005 & 9 & 66 & 20 & 3.3 & 0.8 & -0.2 \\
\hline TR14 & 2005 & 9 & 64 & 16 & 4.1 & 4.0 & 1.4 \\
\hline TR15 & 2005 & 9 & 66 & 15 & 4.3 & 4.6 & 1.5 \\
\hline TR16 & 2005 & 9 & 72 & 25 & 2.8 & 1.0 & 0 \\
\hline TR17 & 2005 & 9 & 65 & 16 & 4.1 & 3.8 & 1.3 \\
\hline TR18 & 2005 & 9 & 65 & 16 & 4.0 & 5.4 & 1.7 \\
\hline
\end{tabular}

Water-quality data were obtained from the Lakes of Missouri Volunteer Program (LMVP). This program consists of citizen volunteers who are trained to collect and process water samples from Missouri lakes. Volunteers monitor surface-water temperature, water clarity (secchi disk transparency), chlorophyll, total phosphorus, total nitrogen, and total suspended solids according to procedures established by LMVP (Obrecht, 1992). Samples are collected once every 3 weeks between April and September for 18 sites (fig. 2) on Table Rock Lake. Repeat sampling is conducted by the same volunteer at each site with site occupation mostly dependent on aligning with visible landmarks. This method might 


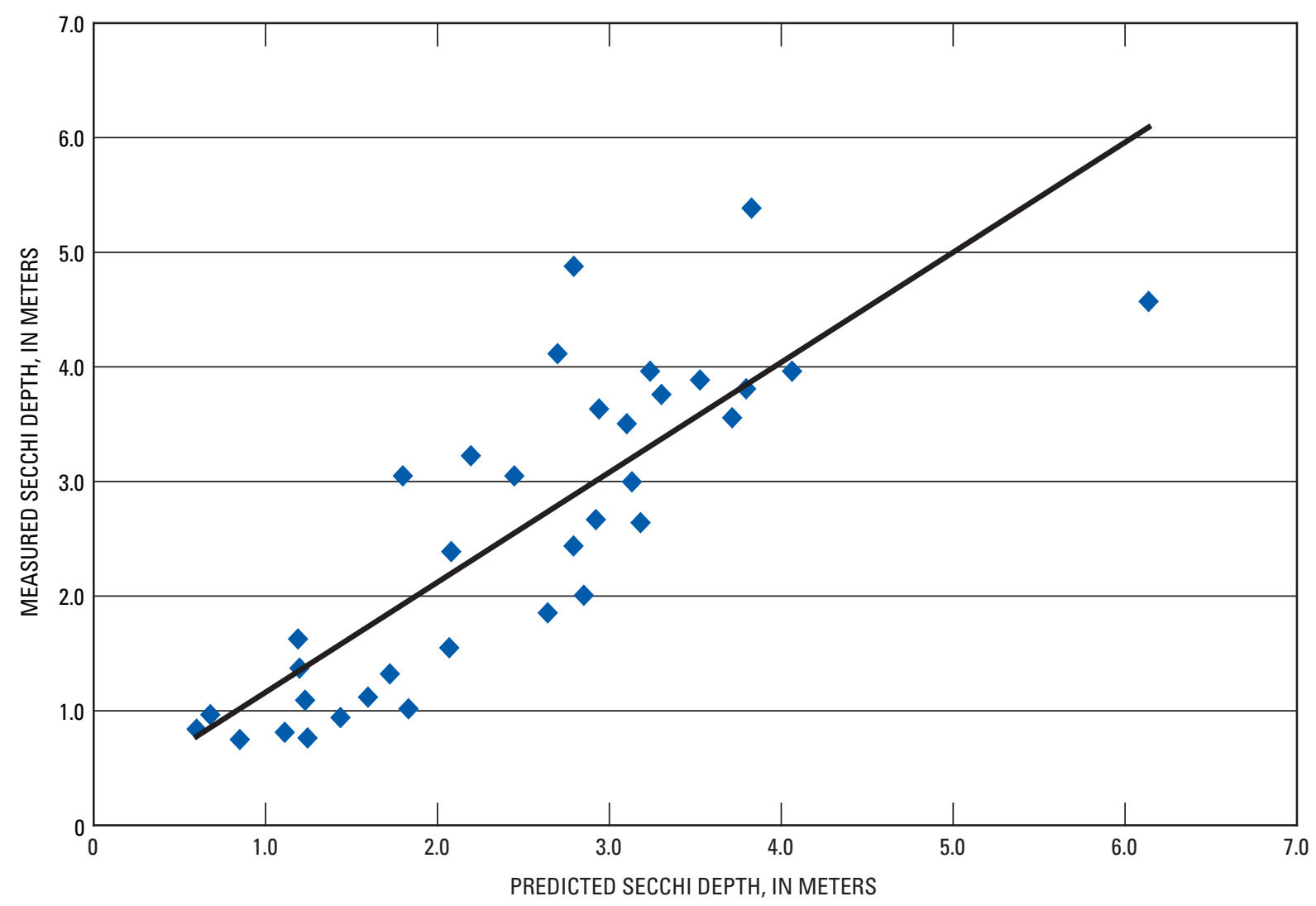

Figure 3. Relation between predicted and measured values of secchi depth for Table Rock Lake.

account for some error in consistently occupying the same sample location, but most volunteers are local residents and have an intricate knowledge of their sampling locations.

Processing of the satellite data was done using ERDAS Imagine software and modified from the procedures described by Olmanson and others (2001). The first step is to produce a water only image so that areas outside of the water body are eliminated from the analysis area. This is accomplished by performing an unsupervised classification on the Landsat image to differentiate water pixels from all others. The scene can then be recoded to create a binary image representing water and terrestrial areas. The water only image is further processed using an unsupervised classification to separate deep, open water areas from areas of the lake affected by vegetation, shoreline, or bottom effects. These areas should be avoided when choosing sample points in the satellite scene.

Sample sites for satellite signature acquisition were selected to coincide with the LMVP water-quality sites. A 3 by 3 ( 9 pixel) area of interest (AOI) was created for each of the sample sites. The AOI size was determined based on a previous study by Kloiber and others (2002) that showed correlation strength improved with an increase in AOI size from 1 to 9 pixels, but was marginal when the AOI was increased beyond 25 pixels. AOIs were centered over the LMVP sample site location and visual inspection performed to avoid areas with potential vegetation, shoreline, or bottom effects. Mean brightness values for each TM band were collected for each sample site AOI (table 1).

Regression analysis was performed using SPSS 14.0 for Windows (SPSS Inc., 2005). The following regression equation developed by Kloiber and others (2002) was used in the analysis of the two scene dates:

$$
\ln (\mathrm{SDT})=a(\mathrm{TM} 1 / \mathrm{TM} 3)+b \mathrm{TM} 1+c
$$

where

$\ln (\mathrm{SDT}) \quad$ is the natural $\log$ of secchi disk transparency depth, in meters, computed from the LMVP water quality data;

$a, b$, and $c$ are the coefficients derived from the regression analysis; and

TM1 and TM3 are bands $1[0.45-0.52$ micrometers $(\mu \mathrm{m})]$ and $3(0.63-0.69 \mu \mathrm{m})$, respectively, from the Landsat $5 \mathrm{TM}$. 


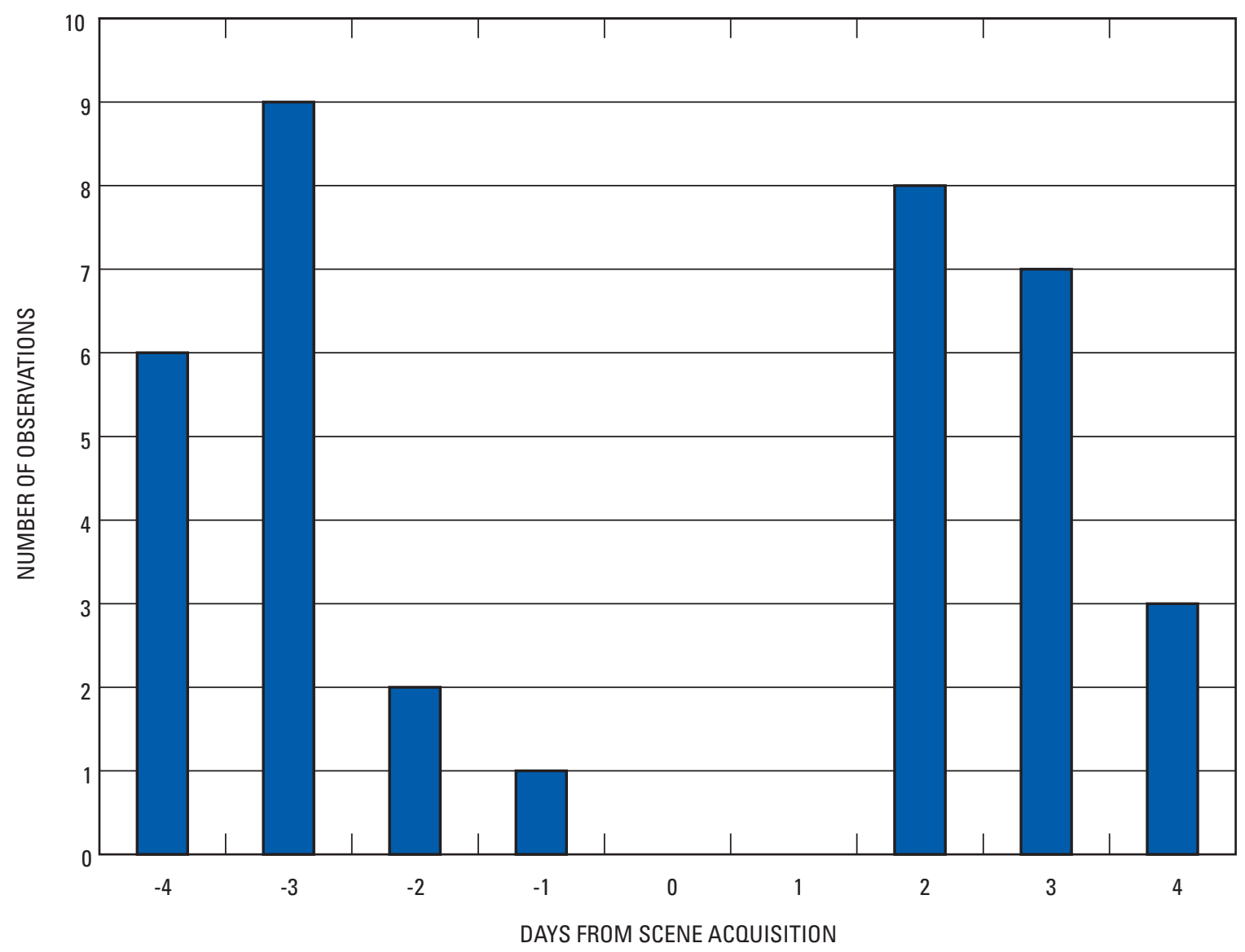

Figure 4. Distribution of field samples with respect to number of days within satellite overpass. All field samples were collected within 4 days with the largest percentage of samples collected 3 days from the time of satellite data collection.

\section{Results}

The regression analysis based on equation (1) produced the following linear model:

$$
\ln (\mathrm{SDT})=-10.061(\mathrm{TM} 1 / \mathrm{TM} 3)+1.788(\mathrm{TM} 1)+0.064
$$

with a reliability $\left(\mathrm{R}^{2}\right)$ of 0.76 and standard error of the estimate of 0.314 . These results are consistent with similar studies using the TM1 and TM3 band relation to secchi disk transparency (Kloiber and others, 2002; Lathrop, 1992). Figure 3 is a plot of the relation between predicted and measured secchi depth for sample locations on Table Rock Lake. The plot shows a strong linear relation $(\mathrm{r}=0.83)$ between measured secchi depth and secchi depth predicted from mean Landsat reflectance values.

Field data collected on the same day as the satellite overpass result in the best regression results. Data collected from 1 to 7 days off the overpass date result in a decreasing strength of correlation (Kloiber and others, 2002; Chipman and others, 2004). All of the field data for this study were collected within 4 days of the satellite overpass (fig. 4) with a distribution as follows: same day ( 0 percent), 1 day ( 3 percent), 2 days (28 percent), 3 days ( 44 percent), and 4 days ( 25 percent). This distribution is inherent in the volunteer sample program as no effort is made to collect all samples on the same day.

Quality and reliability of volunteer collected data have been evaluated by Obrecht and others (1998). They found no statistical differences in data collected by volunteers and data collected by University of Missouri personnel for total phosphorus, total nitrogen, chlorophyll, or secchi depth.

Results of the regression analysis were used to create models using Imagine Spatial Modeler to output images showing the $\ln (\mathrm{SDT})$ and trophic state index (TSI) derived from $\ln (\mathrm{SDT})$ for the entire lake. The relation between TSI and secchi disk depth is defined as:

$$
\mathrm{TSI}=60-14.41 \text { ln secchi disk }
$$

where

TSI is the Carlson trophic state index, and In secchi disk is the natural logarithm of the depth measurement, in meters.

Output images are pixel-level representations of transparency or trophic state that can be used to examine differences in 


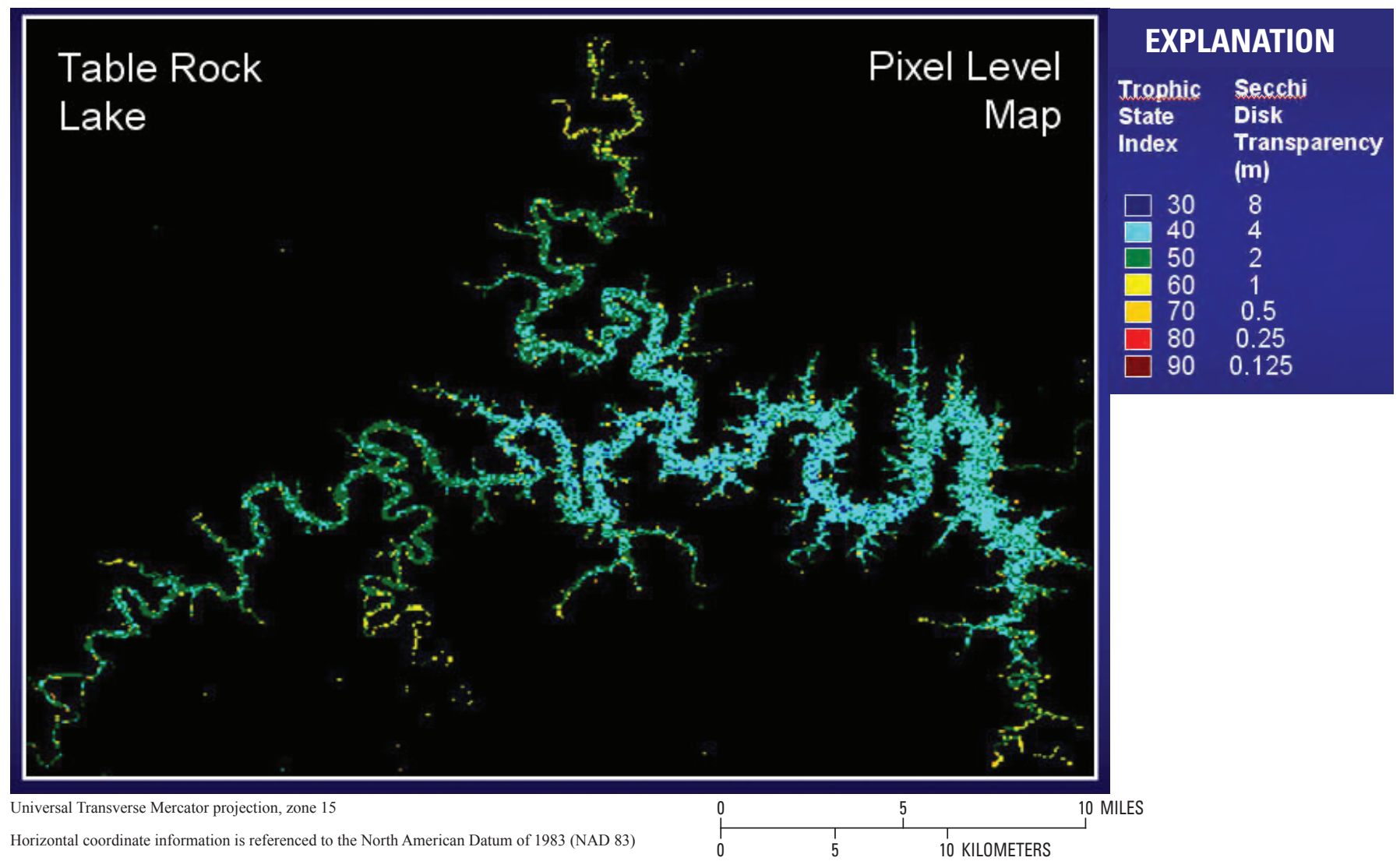

Figure 5. Model predicted trophic state for Table Rock Lake - August 2003. Water quality is degraded in the main tributaries compared to the main channel of the reservoir.

\section{James River Arm}

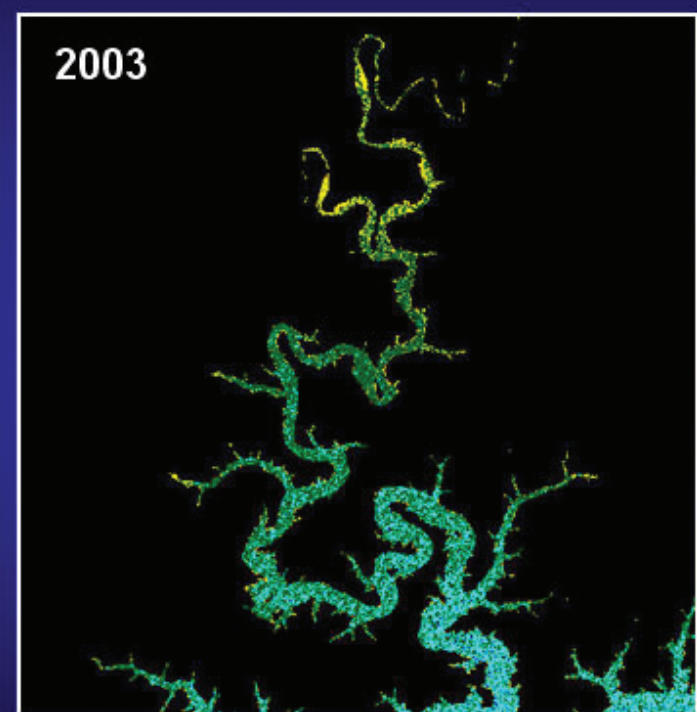

Universal Transverse Mercator projection, zone 15

Horizontal coordinate information is referenced to the North American Datum of 1983 (NAD 83)

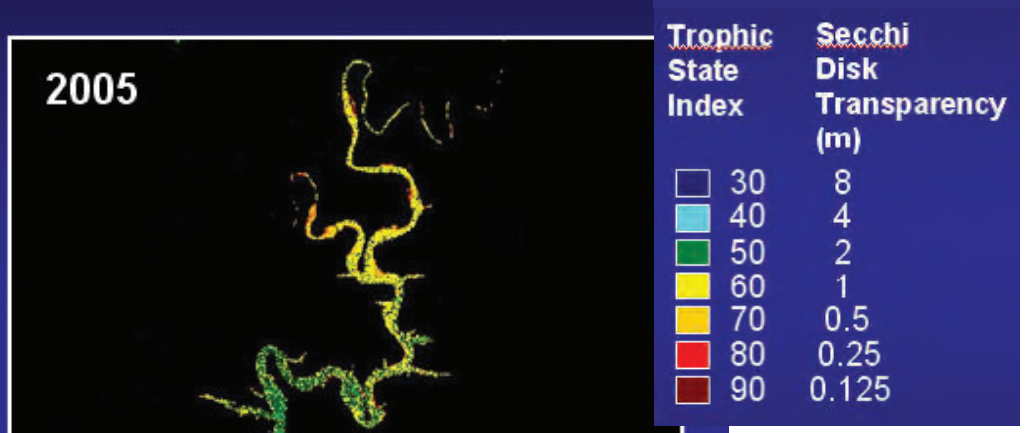

10 MILES

Figure 6. Temporal comparison of model results for the James River arm of Table Rock Lake. Water clarity has decreased in 2005. 
water quality throughout the reservoir (fig. 5). Differences in water quality are readily apparent between the main channel and major tributaries with darker green and yellow pixels in the tributaries representing decreased water clarity. Temporal comparisons can also be made to assess changes in water clarity over time. Figure 6 shows the difference in water clarity for the James River arm of Table Rock Lake between the 2003 and 2005 scene dates. The increase in the TSI value can be seen extending much farther south in the James River arm in the 2005 image.

\section{Summary}

Remote sensing techniques can be effective in monitoring water quality in southwestern Missouri. Mean Landsat brightness values can be used with field data collected by citizen volunteers to produce reliable predictive models of water clarity and trophic state based on measurements of the secchi depth transparency. Predictive models can be used to supplement standard water-quality analyses during periods when field data are not being collected by volunteers. Temporal analyses are possible through the exploitation of the Landsat archive. Pixel-level representations of water clarity and trophic state provide a means of visually interpreting the status of water quality.

\section{Acknowledgments}

Field data used in this study was provided by the Lakes of Missouri Volunteer Program. Special thanks go to Tony Thorpe for his help in acquiring the original data and for discussions on procedures and interpretations of the volunteer data.

\section{References Cited}

Allee, R.J., and Johnson, J.E., 1999, Use of satellite imagery to estimate surface chlorophyll a and secchi disk depth of Bull Shoals Reservoir, Arkansas, USA: International Journal of Remote Sensing, v. 20, no. 6, p. 1057-1072.

Boland, D.H.P., 1976, Trophic classification of lakes using Landsat-1 (ERTS-1) multispectral scanner data: U.S. Environmental Protection Agency, Corvallis, Oreg., EPA-600/376-03, 245 p.

Carlson, R.E.,1977, A trophic state index for lakes: Limnology and Oceanography, v. 22, no. 2, p. 361-369.
Chipman, J.W., Lillesand, T.M., Schmaltz, J.E., Leale, J.E., and Nordheim, M.J., 2004, Mapping lake water clarity with Landsat images in Wisconsin, U.S.A.: Canadian Journal of Remote Sensing, v. 30, p. 1-7.

Fuller, L.M., Aichele, S.S., and Minnerick, R.J., 2004, Predicting water quality by relating secchi-disk transparency and chlorophyll a measurments to satellite imagery for Michigan inland lakes, August 2002: U.S. Geological Survey Scientific Investigations Report 2004-5086, 25 p.

Jones, J.R., and Perkins, Bruce, 1999, Table Rock Lake: An evaluation of factors regulating its trophic state, Final Report to Missouri Department of Natural Resources and U.S. Environmental Protection Agency. University of Missouri, $82 \mathrm{p}$.

Kloiber, S.M., Brezonik, P.L., Olmanson, L.G., and Bauer, M.E., 2002, A procedure for regional lake water clarity assessment using Landsat multispectral data: Remote Sensing of Environment, v. 82, p. 38-47.

Krizanich, G.W., 1986, Landsat trophic state assessment of Fellows Lake: Missouri State University, Masters thesis, $64 \mathrm{p}$.

Lathrop, R.G., 1992, Landsat thematic mapper monitoring of turbid inland water quality: Photogrammetric Engineering and Remote Sensing, v. 58, p. 465-470.

Lathrop, R.G., and Lillesand, T.M., 1986, Utility of thematic mapper data to assess water quality in southern Green Bay and west-central Lake Michigan: Photogrammetric Engineering and Remote Sensing, v. 52, p. 671-680.

Missouri Department of Natural Resources, 2005, Table Rock Lake total maximum daily load information sheet: Missouri Department of Natural Resources Water Protection Program, $4 \mathrm{p}$.

Obrecht, D.V., 1992, Lakes of Missouri Volunteer Program Manual: Lakes of Missouri Volunteer Program, Universtiy of Missouri, $17 \mathrm{p}$.

Obrecht, D.V., Milanick, Margaret, Perkins, B.D., Ready, Diana, and Jones, J.R., 1998, Evaluation of data generated from lake samples collected by volunteers: Journal of Lake and Reservoir Management, v. 14, no. 1, p. 21-27.

Olmanson, L.G., Kloiber, S.M., Bauer, M.E., and Brezonik, P.L., 2001, Image processing protocol for regional assessments of lake water quality: Water Resources Center and Remote Sensing Lab, University of Minnesota.

Ritchie, J.C., Zimba, P.V., and Everitt, J.H., 2003, Remote sensing techniques to assess water quality: Photogrammetric Engineering and Remote Sensing, v. 69, no. 6, p. 695-704.

SPSS for Windows, Release 14.0.1, 2005, Chicago: SPSS Inc. 
Thorpe, A.P., Obrecht, D.V., and Jones, J.R., 2005, Lakes of Missouri Volunteer Program 2005 data report, Department of Fisheries and Wildlife Sciences, University of Missouri.

Wetzel, R.G., 2001, Limnology: lake and river ecosystems (3d ed.): San Diego, CA, Academic Press, 1006 p.

Wezernak, C.T., Tanis, F.J., and Bajza, C.A., 1976, Trophic state analysis of inland lakes: Remote Sensing of Environment, v. 5, p. 147-165. 
Publishing support provided by:

Rolla Publishing Service Center

For more information concerning this publication, contact:

Director

U.S. Geological Survey

Mid-Continent Geographic Science Center

1400 Independence Road, Mail Stop 236

Rolla, M0 65401

(573) 308-3593

Or visit the Mid-Continent Geographic Science Center website at: http://mcgsc.usgs.gov/ 



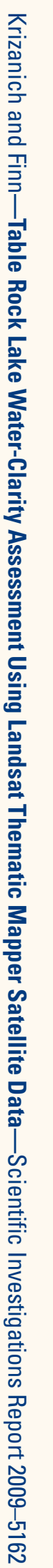

